\title{
Palatability of Herbage and Animal Preference
}

HAROLD F. HEADY

Professor of Forestry (Range Management) University of California, Berkeley.

\section{Introduction}

One important problem in wildland management is how to obtain high sustained grazing use without undesirable vegetational changes. Another problem focuses on the reduction of animal damage to forests in which the animals themselves have little or no economic value in comparison with the value of the eaten plants. Still another centers on the control of undesirable plants with certain animals. A common denominator of these animal-plant relationships is that every grazing animal selects its food from the wide range of plants in natural vegetation, notwithstanding the fact that some animals eat many kinds of foods.

Summarized herein are seminar discussions aimed at (1) defining herbage palatability and animal preference, (2) examining the factors influencing each, and (3) reviewing the effects of preferential grazing on vegetational change. The topic was selected in the belief that a better understanding of palatability and preference will be useful in understanding (1) vegetational changes, (2) formulating better animal management practices, (3) planning vegetational improvement programs, and determining food intake. As in any study of this type, much effort was taken to formulate definitions and to organize a framework that elucidates the known facts and deficits.

The seminar itself is a graduate course in range management. Members in 1963 included students in forestry, zoology, and range management. This summary is the work of the whole class as each student reviewed a part of the literature. All contributed to the discussions and to editing the manuscript. Participants were D. W. Cooper, Jack Hooper, Vernon Mayes, Joseph McBride, Dale McCullough, Rex Pieper, David Taylor, Gene Thorley, and Robert Ziegler.

\section{Rationale}

Palatability is defined as plant characteristics or conditions which stimulate a selective response by animals. Similar definitions have been used by Young (1948), and Cowlishaw and Alder (1960). Webster defines palatable as pleasing to the taste; hence, pleasing to the mind. Preference is reserved for selection by the animal and is essentially behavioral. Relative preference indicates proportional choice among two or more foods. Many factors besides palatability influence food selection. Palatability and preference have been used as synonyms (Ivins, 1952; Soc. Am. Foresters, 1958).

The stimulus-response relationships in food selection and acceptance constitute a complex chain of events. No single plant characteristic has been found that is isomorphic with one physiological measure and one behavioral process. For example, the convenient and well-known primary tastes (salty, sweet, sour, bitter) are no longer adequate because taste results from combined stimulations and there are no corresponding, rigidly specific taste cells (Kare and Halpern, 1961). A continually changing body chemistry undoubtedly influences taste (Young, 1957).

One author has suggested that three interrelated systems exist which regulate food acceptance (Young, 1948). One of these is within the animal body and includes such items as nerve stimuli initiated by energy release, blood sugar level, body temperature, movements in the digestive tract, fatigue of mouth parts, the senses, and others. These have been associated $m_{1} \mathrm{e}$ with the stopping of eating than with the beginning. The reader is referred to Balch and Can;ing (1962) for a discussion of current hypotheses on regulation of food intake by ruminants. This review concentrates on the outward expression of these mechanisms in food selection rather than on the mechanisms themselves. Animal behavior, innate aspects of food habits, and the influence of certain physiological conditions on food preference were considered broadly.

The second system includes the conditioning of an organism by previous feeding habits. Few data, which apply directly to freely grazing animals, are avail- 
able on this point. Results from controlled laboratory experiments and controlled feeding of farm animals indicate that additional work needs to be done on the influence of changing rangefeed conditions on preference and intake.

The third system affecting food intake comprises the nutritive and physical environment of an animal. This system received major emphasis, because the ecological aspects are important in land management.

The three systems mentioned above are $\cdots+$ ainly interrelated in a stimulus-response chain of events that includes recognition of food, movement to the food, appraisal, initial eating, and cessation of eating. Food selection may be exhibited anywhere through the events chain and controlled by any number of mechanisms. "Selective response" describes this situation better than "taste response" in the definition of palatability. The following summarizes the factors considered.

\section{Factors Influencing Relative Preference}

1. PALATABILITY. - Many workers have studied the relationship between chemical composition of plants and their palatability. High positive correlation between protein content and preference by cattle and sheep has been shown (Hobbs et al., 1945; Saltonstall, 1948; Woolfolk, 1950; Hardison et al., 1954; Cook, 1959; Blaser et al., 1960; and others). Foods high in sugars or with sugars added are preferred by cattle (Plice, 1952), pigs (Hanson et al., 1954), calves (Kare and Halpern, 1961), and deer (Mitchell and Hosley, 1936). In work with silage, Allen and Porter (1954) reported high preference was associated with high content of acetic, linolenic, and butyric acids. Hardison et al. (1954) report that high total ether extract indicates high preference. Blaser et al. (1960) found that increased fats (data given are under the title "ether extract") resulted in greater preference. Grasses highest in phosphate and potash were also the most acceptable to livestock in a study by Leigh (1961).

As proteins, sugars, fats, and preferred components of ether extract increase in percentage composition, lignin and crude fiber decrease. Therefore negative correlations of lignin and crude fiber with increased preference were shown in most of the studies mentioned above.

Tannins showed no correlation with preference but tannic acid made hays more acceptable in a study with cattle (Hawkins, 1955). Wilkins et al. (1953) reported a high negative relationship between tannin and preference by cattle for lespedeza varieties. The variety with highest tannin also had the highest percentage of crude protein.

Several compounds, including tannin, coumarins, and nitrates, are believed to decrease forage preference. In analyzing manure affected and unaffected plants, Plice (1952) found that the manure affected plants were always higher in protein, calcium, potassium, iron, fat, nitrates, and vitamins. The normal or unaffected plants were always higher in silica, aluminum, phosphorus, tannin, chloride, and sugars. When sugar was added to manure-affected plants, they became platable and were readily eaten. Sugar per se may not be the cause, as the same results were achieved when saccharine and sodium cyclohexyl sulfamate were added. The spraying of molasses on dry mature grass herbage has been used to promote grazing of plant materials with law palatability (Wagnon and Goss, 1961). The sweet-tooth inclination in pets is well known.

Many conflicting results have been reported in studies conducted to determine what chemical components influence forage preference. The extremes are shown by the positive correlations mentioned above in contrast to the conclusion that there seems to be no consistent correlation between chemical composition of forage and its preference (Johnstone-Wallace and Kennedy, 1944; Hardison et al., 1954).

Perhaps more significant than the amount of any chemical compound is the combination of components. Although protein shows the best correlation of all chemical ingredients with preference of forages by livestock, several investigators believe that total nutritive value of the plant is a better indicator of palatability (Albrecht, 1945; Hardison, 1954; Cook et al., 1956; Cook, 1959). Good reason exists for this conclusion. Reported results which relate chemical composition to preference usually give a list of compounds that increase as preference increases and another list of compounds which decrease. Definitive work to show the effects of each compound with the others held constant has not been successful under grazing conditions. In effect, preference has been correlated with groups of compounds rather than with single items in most studies. With partial regression analysis the effects of one factor could be determined independently of the others.

Within any plant the actual amount of chemical compounds varies with plant parts. Leaves are higher in ether extract and crude protein than stems, and lower in lignin, cellulose, and crude fiber. Fruits and seeds vary in chemical composition among species but commonly are high in crude protein, fats, and soluble carbohydrates (Cook and Harris, 1950a; Van Dyne, 1963). Recent work has shown that sheep and cattle prefer leaves and fruits to stems (Heady and Torell, 1959; Van Dyne, 1963). Whether this is due to chemical content or to some other factor or factors is not known. Fruits 
and leaves can be grazed without stems but stems can hardly be taken without leaves.

Advancing growth stage has frequently been mentioned as a factor correlated with decreasing preference. As grasses and broad-leaved herbs mature, they decrease in crude protein and increase in crude fiber, lignin, cellulose, and other carbohydrates. These are actual changes in the plant as a whole and are further affected by changes in leaf-stem-fruit ratios (McIlvanie, 1942; Cook and Harris, 1950b). Plants also change in succulence and harshness of the foliage. Anatomical studies have shown that position and extent of lignification is associated with curing qualities (Pigden, 1953). Preference changes with growth stage as plants in mixed vegetation do not mature at the same rate. Whether the response is to taste or to some other stimulus such as touch is not known and insufficient evidence is available to evaluate the palatability aspects in these relationships.

Workers in grazing management have attempted to manipulate feed values and, perhaps incidentally, palatability in two ways. One is with mineral soil amendments which speed early growth, delay maturity, and favor some species over others. For example, nitrogen fertilization often increases size of cells without proportionate increase in cell-wall material so the plants are more succulent and less harsh (Russell, 1958). That fertilized range areas are preferred by livestock and deer is a widespread observation. A second is by management system which keeps the forage species from becoming tall and coarse by periodic heavy use and mowing. Clipping studies have shown that changes in the relative amounts of chemical compounds occur after a plant is clipped. It is assumed that similar changes would occur as a result of repeated and periodic grazing and that the relative amounts of certain chemical compounds influence palatability (McIlvanie, 1942; Cook et al., 1953).

Climate, topography, and soil moisture have been listed as affecting palatability (Cook, 1959). These habitat conditions affect such palatability aspects of plants as chemical composition, turgidity, and harshness of foliage. They also affect other preference factors but studies have not been made which separate the two sets of factors.

External form of a plant is a palatability factor. Preference is probably related to presence of awns, spines, hairiness, position of leaves, stickiness, and texture. The relationship of odor to preference is little understood. It is mentioned here because odor-producing glands are an external plant feature. Odors may also originate internally and become released only with mastication of the plant tissues.

In summary, one of the factors affecting preference of forage by animals is palatability which is here defined as a plant characteristic that stimulates a selective animal response. Presumably, chemical composition is the most important palatability factor. At least it is the one on which most information is available. This is the result of emphasis on nutritive values rather than on research into palatability per se. Other factors such as proportion of leaves, stems, and fruits; plant growth stages; past grazing use; climate; topugraphy; soil moisture; and fertility have been related to palatability mainly through their influence on chemical components. Little information is available on external form, texture, and odor as they may influence preference.

2. ASSOCIATED SPECIES.Preference for a given forage species is contingent upon the availability of other choices. Data of the type presented by Hurd and Pond (1958) and
Hooper (1960) are used to illustrate this point. The first paper showed that Stipa columbiana had a higher preference rating and Danthonia intermedia a lower rating in the sagebrush type than they had in other types. Hooper found different degrees of browsing by deer on the same species when it occurred on different soil types. Observations indicate that some species are grazed heavily when they occur in small quantities throughout a "better" forage, whereas in dense stands the use is light. This has been reported for Artemisia tridentata (Stoddart and Smith, 1955), Ceanothus thyrsiflorus (Hooper, 1962) and Agropyron simithii on lowland sites (Tomanek et al., 1958). Preference in relation to differences in species composition on one habitat was studied by Heady and Torell (1959).

No one denies that preference for a species varies with associated species. However, information which defines the functioning of the variables involved is scarce. For example, palatability factors would be expected to change with habitat, but this possibility is seldom mentioned in statements concerning the relations of preference to availability of other choices.

3. CLIMATE, SOIL, TOPOGRAPHY.-These parts of the total system in which forage is produced and eaten have been mentioned as influencing palatability. They also have a direct bearing on animal behavior and thereby further influence food preference. For example, grazing animals change their preferences with differences in temperature and rainfall (Castle and Halley, 1953; Corbett, 1953) and wetness of foliage (Tayler, 1953). Animal movements change with drought cycles, soil texture (heavy clay is avoided in wet weather), and steepness of slope. Animal migrations are influenced by weather. 
4. KIND OF ANIMAL-Animal species differ markedly in their food habits, with each species showing innate preferences for certain plants, parts of plants, or plants in particular growth stages. It is not the purpose here to catalogue food habits. Interpretation of differences would be most difficult because grazing animals exhibit variation in preferred foods from one location to another (Dasmann, 1949; Leach, 1956), from one season to another (Heady and Torell, 1959; Leach, 1956), over a period of a few days (Nichol, 1938), within the same day (Van Dyne, 1963), and among individuals (Heady and Torell, 1959; Van Dyne, 1963). Reducing the available feed supply by grazing has altered preference (Corbett, 1953; Dasmann, 1949; Julander, 1958; Van Dyne, 1963). On the other hand, relative utilization of a species did not appear to be influenced by frequency, abundance, or amount of herbage (Hurd and Pond, 1958). Additional papers on food habits for a variety of animals are Smith (1954), Talbot (1963), Johnston and Buxton (1949), Tevis (1958), Cringan (1957), Gaffney (1941), Scheffer (1951), Buechner (1947), Johnson (1961), Fitch (1948), and Vorhies and Taylor (1933). Since many species of grazing animals inhabit the same area, additional knowledge of food habits, including preferences, is needed so that vegetation may be controlled to give desirable animals their preferred foods.

5. ANIMAL PHYSIOLOGY.Forage preferences by domestic animals have been shown to be related to pregnancy, fatness, lactation, and hunger. Sight, smell, touch, taste, instinct, and experience probably all bear on preference. These are complex and interacting mechanisms whose influence has been observed but not measured and explained.
In summary, this treatment of preference follows closely the one suggested by Cowlishaw and Alder (1960) who recognized four groups of factors. One is palatability, which includes attributes of the plant that the animal can recognize. The second includes conditions surrounding available herbage such as microclimate, soil conditions, relative abundance, contamination, and mixture of species. These factors play a dual role in affecting palatability and animal behavior. Third is the previous history of the animal in both the sense of evolution of food habits and learning by the individual through repeated experience. The last group includes the physiological state of the animal. The act of selecting food is undoubtedly influenced by all four and can only be finally understood in terms of interactions among them. Unfortunately, most studies to date have concentrated on single factors or, even more simply, just recording the magnitude of preference.

\section{Methods Used to Determine Forage Preference}

Evaluation of evidence used to describe the results of animal selection and to explain the various mechanisms involved focused attention on the methods employed. Several defects in methodology came to light, so a section giving brief evaluations is included. The amount of herbage which disappears during grazing and the percentage of current growth removed are termed forage utilization in range management and wildlife management. Because correct utilization is an important aspect of rangeland management, numerous methods have been devised to measure what and how much herbage has been removed. These techniques are also used to determine preference which is usually expressed as the relative use made of different species. Chapter 5 in Range Research: Basic Problems and Techniques (Am. Soc. Range Mgmt., 1962) is a recent review of these methods and it seems unnecessary to repeat the material here.

Preference may be expressed in terms of the proportionate time an animal spends grazing different species. Cafeteria plots of several species in pure stands are used to study preference, which is measured in terms of percentage of time animals graze in each plot and the amount of herbage removed. Giving penned animals a choice of two or three foods is a similar technique. These methods are described on pages 74-77 in the above reference.

Other techniques that give information on animal preference include analysis of stomach contents (Leach, 1956; Talbot, 1963), fecal material (Hercus, 1960; Hardison et al., 1954), collections from esophageal fistulas (Heady and Torell, 1959), and from stomach fistulas (Lesperance et al., 1960). Fistulas have been used for many years in nutritional studies but only recently with promising results in examining food preference.

Preference has been expressed in different ways. General terms such as excellent, good, fair, and poor and as many as ten numbered classes are common. Data have been presented in frequency indexes based on number of stems or plants or plots grazed. Weight of clippings taken before and after grazing or inside and outside exclosures give indications of differential use, hence preference. The proportions of time animals were eating various foods and number of animals eating each food at certain time intervals are other expressions of preference. The proportion of species and plant parts in materials collected from fistulas as ratios to the feed offered measures whether the species are selected or avoided. 
In general the methods used to measure preference are those employed primarily for other purposes such as determining grazing capacity, effects of grazing on vegetation, forage production, food intake, animal nutrition, and range utilization. Imperfect results are not surprising and were indicated by Cook and Stoddard (1953). In fact these techniques are not completely satisfactory for the purposes employed. For example, all the methods of determining forage use are based on differences between grazed and ungrazed conditions and on computing the eaten portion from the herbage remaining. Accurate measurement of what the freely grazing animal has eaten is most difficult, especially when the forages are mixed. Analysis of stomach contents requires fistula operations or sacrifice of animals, and the results are biased in favor of slowly digestible materials. Esophageal fistulas seem to be the most promising aid to determining what is eaten. This technique does not give quantity consumed, nor have inherent variability and bias been studied.

Several points stand out concerning methods of determining preference. Techniques should be perfected, results should be expressed in a way that shows relative use in relation to relative availability, and studies which concentrate on preference are needed. The latter should include controlled experimental manipulations and measurements throughout the stimulusresponse system of food selection and acceptance.

\section{Effects of Selective Grazing on Vegetational Change}

A voluminous literature leaves no doubt that animals influence vegetation. The seminar group accepted this point and sought information on the effects of preferential grazing on vegetation. An attempt was made to separate this effect from other closely associated grazing factors, among which are frequency, intensity, and season of grazing; trampling; and construction of nests or shelters. In the words by Stoddardt and Smith (1955, pg. 122): "Too intensive grazing is marked by a disappearance of the preferred plants or of those physiologically less resistant to grazing. Less preferred or more resistant plants may survive and replace the removed plants." Logically, the more preferred species should be eaten first under any intensity of grazing, including light grazing, and the less preferred ones left ungrazed. This weakens the preferred species and promotes their replacement. Given enough time, the process should result in vegetaticn composed of plants with low palatability. Contrary to this are innumerable accounts of range improvement through increase of preferred plants when grazing pressures were lightened and of areas grazed by wild animals through recent geological time without apparent destruction of preferred forage species. Our interest in palatability and preference stems from this paradox.

The virtual elimination of Hypericum perforatum by the Klamath weed beetle when it was introduced into northwestern California (Huffaker, 1951) is an example of vegetational change caused by an animal with a very narrow food spectrum. Other examples of animals feeding on single or a few plant species are common. These situations give one extreme in the food selection process. It is a relatively simple one to measure.

Grazing studies with domestic and game animals have, for the most part, concentrated on the effects of overgrazing and in many, intensity of use overshadows selection as a factor influencing vegetational change. Feed supplies become so low that animals are forced to graze plants they normally would avoid. Vegetational changes under these conditions are frequently compared with those in exclosures which give the other extreme of no grazing at all or, on occasion, an unknown amount of grazing by wild animals attracted to the exclosure. Ellison (1960) has reviewed approximately 250 papers on the influence of grazing on plant succession. Effects of domestic livestock on range land received major attention in the review. Big game animals and rodents were given lesser emphasis and grazing systems were considered. Additional papers not cited by Ellison broaden the coverage of his review and strengthen many of his conclusions. These papers were Cooper (1928), Branson and Payne (1958), Heady (1961), Julander et al. (1959), Osborn and Allan (1949), Ratliff (1962), and Riegel (1942). A number of Ellison's conclusions on effects of herbage removal (pg. 45) are quoted below:

Generally speaking, the effect of grazing certain species in a community is to handicap those species and encourage others. Under range conditions, where the animals cannot be controlled as they are in pastures, the effect of selective grazing is commonly to reduce the proportion of palatable species. Obviously differences in palatability are not the whole explanation for trends under grazing: differences in growth form or phenology may also play an important part.

Successional trends are roughly proportional to grazing intensity: they are pronounced under severe grazing, and in some instances difficult to distinguish at light or moderate levels. Some observations suggest that palatable plants respond as favorably under light grazing as under no grazing, or as favorably under moderate as under light grazing. Other studies do show an appreciable effect of grazing at light intensities. Too little is known about the effects of light or moderate grazing to permit any very meaningful conclusion.

Even though a large body of 
information supports the hypothesis that animals cause large changes in vegetation, the conclusion that selective grazing of species is a major factor may be questioned. The weight of data points either to intensity of forage use or to both factors operating together. Selection undoubtedly occurs when animals eat, but the effects of selection have not been adequately documented to establish its separate effect, particularly at light and moderate grazing intensities. A confusing case in point is the often observed but seldom discussed effect of repeated grazing and heavy intensity of use on favorite areas in the lightly stocked pasture.

Benefits of grazing have been reviewed by Ellison (1960) and the evidence is not great that grazing animals contribute markedly to the welfare of range vegetation. Vast areas of healthy, grazed grasslands, which exist in the world and contain preferred species, suggest balance, at least, between animals and vegetation. Perhaps there are benefits of grazing that have not been determined? Perhaps selectivity is more important at certain intensities of grazing than at others? Perhaps methods haven't been perfected or used long enough to show slowly moving trends?

\section{Epilogue}

Restricting discussions to palatability and preference and to effects of selective grazing on vegetation is difficult. Applicable data is available in papers on animal nutrition, food habits, forage utilization, intensity of grazing, and others. Terms must be defined because wide variation in usage over time in range management and between disciplines concerned with food intake is confusing. Lack of experimentation, difficulties of measuring vegetation and animal behavior precisely, and the complexity of the subject make detailed comparison of published results risky. However, several points stand out.

Of the many factors that may influence palatability, only chemical composition has received considerable attention, and this was mostly incidental to studies of animal nutrition. A large body of data is available on food habits of different animals, but preference in the sense of food eaten in relation to food available is not often mentioned. Forage utilization determinations leave much to be desired in methodology and do not separate the use by different animals on the same range. Vegetational changes resulting from grazing seem to be correlated more with intensity of range stocking and use than with preference, notwithstanding a widespread belief that changes are due in large measure to selection. In short, too little definitive information is available for an adequate understanding of palatability and preference and the effects of selective grazing on vegetational change. Enough is available to warrant separate definitions of palatability and preference.

\section{LITERATURE CITED}

AlbRecht, W. A. 1945. Discriminations in food selection by animals. Sci. Month. 60:347-352.

Allen, R. S. ANd A. R. Porter. 1954. Effect of added ground corn on the consumption and palatability of stacked legume grass silage. J. Dairy Sci. 37:658.

Am. Soc. Range Mgmt. 1962. Basic problems and techniques in range research. Nat'l Acad. Sci. Pub. 890. $341 \mathrm{pp}$.

Balch, C. C. and R. C. Campling. 1962. Regulation of voluntary food intake in ruminants. Nutri. Abstracts and Reviews 32:669-686.

Blaser, R. E., R. C. Hames, JR., H. T. BRYANT, W. A. HaRDISON, J. P. Fontenot and R. W. ENGel. 1960. The effect of selective grazing on animal output. Proc. 8th Intern. Grassl. Congr. 8:601-606.

Branson, F. A. and G. F. Payne. 1958. Effects of sheep and gophers on meadows of the Bridger Mountains of Montana. J. Range Mgmt. $11: 165-169$.

BUECHNER, H. K. 1947. Livestockantelope relationships in west Texas. The Cattleman 34:80-84.
Castle, M. E. and R. J. Halley. 1953. The grazing behaviour of dairy cattle of the National Institute for Research in Dairying. Brit. J. Anim. Behav. 1:139-143.

Cook, C. W. 1959. The effect of site on the palatability and nutritive content of seeded wheatgrasses. J. Range Mgmt. 12:289-292.

Cook, C. W. AND L. E. Harris. 1950a. The nutritive content of the grazing sheep's diet on summer and winter ranges of Utah. Utah Agr. Exp. Sta. Bull. 342. 66 pp.

Cook, C. W. and L. E. HarRIS. 1950b. The nutritive value of range forage as affected by vegetation type, site, and stage of maturity. Utah Agr. Exp. Sta. Bull. 344. 45 pp.

Cook, C. W. and L. A. Stopdart. 1953. The quandary of utilization and preference. J. Range Mgmt. $6: 329-335$.

Cook, C. W., L. A. Stoddart and L. E. HARRIS. 1953. Effect of grazing intensity upon the nutritive value of range forage. J. Range Mgmt. 6:51-54.

Cook, C. W., L. A. Stoddart aNd L. E. Harris. 1956. Comparative nutritive value and palatability of some introduced and native forage plants for spring and summer grazing. Utah Agr. Exp. Sta. Bull. $385.39 \mathrm{pp}$.

CoOper, W. S. 1928. Seventeen years of successional change upon Isle Royale, Lake Superior. Ecology 9:1-5.

CoRBETT, J. L. 1953. Grazing behaviour in New Zealand. Brit. J. Anim. Behav. 1:67-71.

Cowlishaw, S. AND F. Allder. 1960. The grazing preferences of cattle and sheep. J. Agr. Sci. 54:257-265.

Cringan, A. T. 1957. History, food habits and range requirements of the woodland caribou of continental North America. Trans. N. A. Wildl. Conf. 22: 485-500.

DASMANN, W. P. 1949. Deer-livestock forage studies on the interstate winter deer range in California. J. Range Mgmt. 2: 206-212.

ELLISON, L. 1960. Influence of grazing on plant succession of rangelands. Bot. Review 26:1-78.

Fircir, H. S. 1948. Ecology of the California ground squirrel on grazing lands. Am. Midland Naturalist 39:513-596.

GaFFNEY, W. S. 1941. The effects of winter elk browsing, South Fork of the Flathead River, Montana. J. Wildlife Mgmt. 5:427-453.

Hanson, L. E., J. M. Russo AND E. F. FERRIN. 1954. Dry rations for pigs weaned at 3 weeks. Minn. Agr. Exp. Sta. Mimeo. H-134.

HARDISON, W. A., J. T. REID, C. M. MARTIN AND P. G. WOOLFOLK. 1954. Degree of herbage selection by grazing cattle. J. Dairy Sci. 37:89-102.

HaWKINS, JR., G. E. 1955. Consumption and digestibility of Lespedeza sericea hay and alfalfa hay plus gallotannin. J. Dairy Sci. 38:237243. 
Heady, H. F. 1961. Continuoùs vs. specialized grazing systems: A review and application to the California annual type. J. Range Mgmt. 14:182-193.

Heady, H. F. AND D. T. TORELl. 1959. Forage preferences exhibited by sheep with esophageal fistulas. J. Range Mgmt. 12:28-34.

Hercus, B. H. 1960. Plant cuticle as an aid to determining the diet of grazing animals. Proc. 8th Intern. Grassl. Congr. 8:443-447.

HobBs, C. S., W. D. Gallup and B. R. TAYLOR. 1945. The composition and apparent digestibility of bluestem grass in the growing stage, and in the dry and hay stages when supplemented with cottonseed cake. J. Anim. Sci. 4:395-402.

HOOPER, J. F. 1962. Influence of soils and deer browsing on vegetation following logging redwoodDouglas fir near Korbel, Humboldt County. M.S. thesis, Univ. of Calif., Berkeley.

HufFaker, C. B. 1951. The return of native perennial bunchgrass following the removal of Klamath weed (Hypericum perforatum $L$.) by imported beetles. Ecology 32: 443-458.

Hurd, R. M. and F. W. Pond. 1958. Relative preference and productivity of species on summer cattle ranges, Bighorn Mountains, Wyoming. J. Range Mgmt. 11:109-114.

IviNs, J. D. 1952. The relative palatability of herbage plants. J. Br. Grassl. Soc. 7:43-54.

Johnson, D. R. 1961. The food habits of rodents on rangelands of southern Idaho. Ecology 42:407-410.

Johnston, H. B. AND D. R. Buxton. 1949. Field observations on locusts in eastern Africa. Anti-Locust Bull. 5. 74 pp.

JoHNSTONE-WALlACE, D. B. AND $\mathrm{K}$. KENNEDY. 1944. Grazing management practices and their relationship to the behaviour and grazing habits of cattle. J. Agr. Sci. 34: 190-197.

Julander, O. 1958. Techniques in studying competition between big game and livestock. J. Range Mgmt. 11:19-21.

JulaNDER, O., J. B. Low AND O. W. MORRIS. 1959. Influence of pocket gophers on seeded mountain range in Utah. J. Range Mgmt. 12:219224.

KARE, M. R. AND B. P. HaLPern. 1961. Physiological and behavioral as- pects of taste. Univ. Chicago Press. $149 \mathrm{pp}$.

LEACH, H. R. 1956. Food habits of the Great Basin deer herds of California. Calif. Fish and Game 42:243-308.

LEIGH, J. H. 1961. The relative palatability of various varieties of weeping love grass (Eragrostis curvula (Schrad.) Nees). J. Br. Grassl. Soc. 16:135-140.

LeSPERANCE, A. L., E. H. JENSEN, V. R. Bohman aNd R. A. MAdSEN. 1960. Measuring selective grazing with fistulated steers. J. Dairy Sci. 43: 1615-1622.

Mitchell, H. L. AND N. W. Hosley. 1936. Differential browsing by deer on plots variously fertilized. Black Rock Forest Papers 1:24-27.

McIlvanIE, S. K. 1942. Carbohydrate and nitrogen trends in bluebunch wheatgrass, Agropyron spicatum, with special reference to grazing influences. Plant Physiology 17:540-557.

NICHOL, A. A. 1938. Experimental feeding of deer. Ariz. Agr. Exp. Sta. Tech. Bull. $75.39 \mathrm{pp}$.

OSBORN, B. AND P. F. AlLAN. 1949. Vegetation of an abandoned prairie-dog town in tall grass prairie. Ecology 30: 322-332

Pigden, W. J. 1953. The relation of lignin, cellulose, protein, starch and ether extract to the "curing" of range grasses. Canadian J. Agr. Sci. 33: 364-378.

PLICE, M. J. 1952. Sugar versus the intuitive choice of foods by livestock. J. Range Mgmt. 5:69-75.

RATLIFF, R. D. 1962. Preferential grazing continues under rest-rotation management. P.S.W. Forest and Range Exp. Sta. Research Note $206.6 \mathrm{pp}$.

RIEGEL, A. 1942. Some observations of the food coactions of rabbits in western Kansas during periods of stress. Trans. Kans. Acad. Sci. 45:369-375.

RUSSELL, E. J. 1958. Soil conditions and plant growth. 8th Ed. Longman's, Green and Co., London, N. Y. and Toronto. $635 \mathrm{pp}$.

Saltonstall, JR., L. 1948. The measurement of the quantity and quality of pasture herbage consumed by sheep: A technique study. Ph.D. Thesis, Cornell Univ.

Scherfer, V. B. 1951. The rise and fall of a reindeer herd. Sci. Mon. 73:356-362.

SmITH, D. R. 1954. The bighorn sheep in Idaho; its status, life history and management. Idaho Dept. of Fish and Game. Wildlife Bull. 1. 154 pp.

Soc. Am. Foresters. 1958. Forestry terminology: A glossary of technical terms used in forestry. 3rd Ed. Washington, D. C. $97 \mathrm{pp}$.

Stodpart, L. A. aNd A. D. Smith. 1955. Range management. 2nd Ed. McGraw-Hill Book Co., N. Y. $433 \mathrm{pp}$.

TAlBot, L. M. 1963. The ecology of Western Masailand, East Africa, $\mathrm{Ph}$. D. Thesis, Univ. of Calif., Berkeley.

TAYLER, J. C. 1953. The grazing behaviour of bullocks under two methods of management. Brit. J. Anim. Behav. 1:72-77.

TEVIS, JR., L. 1958. Interrelations between the harvester ant, Veromessor pergandei (Mayr) and some desert ephemerals. Ecology 39:695-704.

TomaneK, G. W., E. P. Martin and F. W. Albertson. 1958. Grazing preference comparisons of six native grasses in the mixed prairie. J. Range Mgmt. 11:191-193.

VAN Dyne, G. M. 1963. Forage intake and digestion by cattle and sheep on a common dry foothill annual range. Ph.D. Thesis, Univ. of Calif., Davis.

VORHIES, C. T. AND W. P. TAYLOR. 1933. The life histories and ecology of jack rabbits, Lepus alleni and Lepus californicus ssp. in relation to grazing in Arizona. Ariz. Agr. Exp. Sta. Tech. Bull. 49: 470-587.

WaGNON, K. A. AND H. Goss. 1961. The use of molasses to increase the utilization of rank, dry forage and molasses-urea as a supplement for weaner calves. J. Range Mgmt. 14: 5-9.

WILKINS, H. L., R. P. Bates, P. R. HENSON, I. L. LINDAHL AND R. E. DavIs. 1953. Tannin and palatability in sericea-lespedeza, $L$. cuneata. Agron. J. 45:335-336.

Woolfolk, P. G. 1950. Development and evaluation of the chromogen (S) method for determining digestibility and consumption of feeds by ruminants. Ph.D. Thesis, Cornell Univ.

Young, P. T. 1948. Appetite, palatability and feeding habit: A critical review. Psychol. Bull. 45:289320.

Young, P. T. 1957. Psychologic factors regulating the feeding process. Am. J. Clinical Nutr. 5:154161 . 